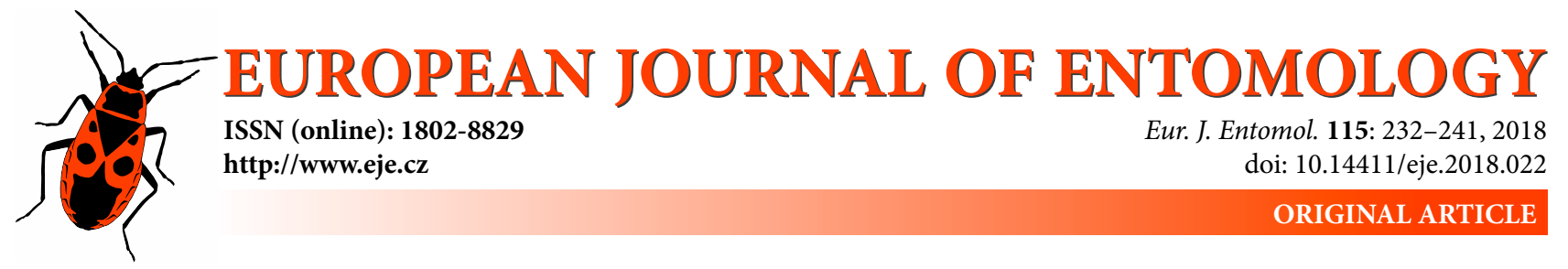

\title{
Functional responses and intraspecific competition in the ladybird Harmonia axyridis (Coleoptera: Coccinellidae) provided with Melanaphis sacchari (Homoptera: Aphididae) as prey
}

\author{
Pengxiang WU ${ }^{1,2}$, Jing ZHANG ${ }^{1,2}$, Muhammad HASeEB ${ }^{3}$, Shuo YAN ${ }^{4}$, Lambert KANGA ${ }^{3}$ and Runzh ZHANG $^{1, *}$ \\ ${ }^{1}$ Department of Entomology, State Key Laboratory of Integrated Management of Pest Insects and Rodents, Institute of Zoology, \\ Chinese Academy of Sciences, \#1-5 Beichen West Rd., Chaoyang, Beijing 100101, China; e-mails: wupengxiang@ioz.ac.cn \\ (Wu P.X.), jing1.zhang@famu.edu (Zhang J.), zhangrz@ioz.ac.cn (Zhang R.Z.) \\ ${ }^{2}$ University of Chinese Academy of Sciences, Beijing 100049, China \\ ${ }^{3}$ Center for Biological Control, Florida A\&M University, Tallahassee, FL 32307-4100, USA; \\ e-mails: Muhammad.Haseeb@famu.edu (Haseeb M.), lambert.kanga@famu.edu (Kanga L.) \\ ${ }^{4}$ National Agricultural Technology Extension and Service Center, Beijing 100125, China; e-mail: yanshuo2011@foxmail.com \\ (Yan S.)
}

Key words. Coleoptera, Coccinellidae, Harmonia axyridis, Hemiptera, Aphididae, Melanaphis sacchari, functional response, intraspecific competition

\begin{abstract}
Functional responses at each developmental stage of predators and intraspecific competition associated with direct interactions among them provide insights into developing biological control strategies for pests. The functional responses of Harmonia axyridis (Pallas) at each developmental stage of Melanaphis sacchari (Zehntner) and intraspecific competition among predators were evaluated under laboratory conditions. The results showed that all stages of $H$. axyridis displayed a type II functional response to $M$. sacchari. Based on Holling's disc equation, the instantaneous searching rates were highest (a) and handling time was shortest $\left(T_{\mathrm{h}}\right)$ of fourth instar larvae $\left(a=0.8818 ; T_{\mathrm{h}}=3.9 \mathrm{~min}\right)$ and female adults $\left(a=0.9881 ; T_{\mathrm{h}}=3.0 \mathrm{~min}\right)$ at larval and adult stages, respectively. The coefficients of mutual interference $(m)$ assessed by the intraspecific competition equation were higher for fourth instar larvae $(m=0.4764)$ and female adults $(m=0.4183)$. The present study indicates that fourth instar and female adult were more effective stages of $H$. axyridis in the context of biological control but suitable predator densities need to be considered before natural enemy release.
\end{abstract}

\section{INTRODUCTION}

Melanaphis sacchari (Zehntner) (Hemiptera: Aphididae) is a perennial pest of Sorghum bicolor L. Moench and Saccharum officinarum $\mathrm{L}$. which has a wide economic impact (Singh et al., 2004). Melanaphis sacchari originates from Java, Indonesia (Zehntner, 1897). In North America, M. sacchari has been recorded as a sugarcane pest in Florida (Mead, 1978; Denmark, 1988) and Louisiana (Hall, 1987; White et al., 2001). Melanaphis sacchari is initially reported on sorghum when their largely damaging populations invaded in Beaumont, Texas (Villanueva et al., 2014). Melanaphis sacchari is described as a distinct species (Blackman \& Eastop, 2006), and their clones are defined by geography including Africa, China, Australia, USA and South America rather than by the host plant (Nibouche et al., 2014). Over the past several years, M. sacchari has caused measurable economic effects due to the damaged plant growth correlated with the sticky "honeydew" covering the plant. Melanaphis sacchari transmits the sugarcane yellow leaf virus causing a $25 \%$ reduction in sugarcane yields (Akbar et al., 2010). Control of M. sacchari is difficult as pesticides cannot penetrate the greater canopy of sorghum. Pre- and post-harvest restrictions exacerbate the challenge of pesticide use (Armstrong et al., 2016). Melanaphis sacchari cannot destroy sorghum in a short term period, but the large populations growing out of control lead to the chlorosis correlated with damage of plant tissues because of the rapid aphid reproduction (Colares et al., 2015). Melanaphis sacchari can continue injuring the plants at grain-filling stage and affecting their seeds both in quality and quantity (Chang \& Fang, 1984; van den Berg et al., 2003). Moreover, if the M. sacchari colony has the characteristic of thermal tolerance, it could contribute significantly to its pest status under hot summer conditions

\footnotetext{
* Corresponding author; e-mail: zhangrz@ioz.ac.cn
} 
(Pendleton et al., 2009). Melanaphis sacchari is also good at utilizing wild grasses in the field (Singh et al., 2004).

There are 47 species of natural enemies that have been recorded as biological control agents of $M$. sacchari (Singh et al., 2004). Many studies now indicate that predators often locate their prey by using plant volatiles (Takabayashi \& Dicke, 1996; Arimura et al., 2005; Turlings \& Ton, 2006). The predators search for aphids through honeydew derived from aphids (Hatano et al., 2008; Verheggen et al., 2008) and volatiles released by damaged plants (James et al., 2005; Sasso et al., 2009). Multicolored coccinellid Harmonia axyridis Pallas has the potential to be a biocontrol agent of aphids throughout Asia, America and Europe (Koch, 2003), and this predacious coccinellid is the effective predator of aphids in natural environments (Mogi, 1969; Choi \& Kim, 1985; McClure, 1987; Hong, 1996). The primary factor to determine whether $H$. axyridis can be a suitable candidate for biological control of $M$. sacchari is their foraging capacity. Various aphidiphagous responses of $H$. axyridis have been performed in previous studies (Lou, 1987; Hu et al., 1989; He et al., 1994; Seo \& Youn, 2000), but its functional response to $M$. sacchari is still unstudied. The functional response of a predator to the dynamic of prey densities depends on their instantaneous searching rate and handling time (Hassell et al., 1976). These parameters will provide a valuable reference for augmentative releases of $H$. axyridis as a biological control agent of $M$. sacchari in natural habitats. Releases of $H$ axyridis eggs, larvae and adults have been studied (Tedders \& Schaefer, 1994; Trouve et al., 1997; Ferran et al., 1998; Kitagami \& Ohkubo, 1998; Kuroda \& Miura, 2003). Growth stage of natural enemies needs to be considered as their searching rates and handling time vary with the developmental stages (Varley et al., 1973; Dixon, 2000). Complex predator-prey systems are attributed to the interactions not only between predator and prey, but also between predator individuals, especially in circumstances where competition is intense (Papanikolaou et al., 2016).

Predatory coccinellids serve as biological control agents of pests in many crops (Ferran et al., 1996). Interactions among these predators, and competition for resources (prey and space), influence their impact on biological control. Our preliminary observations indicated that foraging efficiency, and hence the effectiveness of biological control, is reduced when too few or too many of these predators are present. Interactive competition is a density-dependent process including indirect and direct interactions between predators (Begon et al., 1996). Intraspecific competition occurs via direct interactions between predator individuals of same species (Hassell, 1978). Several models have been performed to quantify mutual interference using phenomenological (Hassell \& Varley, 1969) or mechanistic (Beddington, 1975; DeAngelis et al., 1975; Crowley \& Martin, 1989) approaches, which indicates that foraging behavior is not only prey-dependent but also a predator-dependent process. Thus, consideration of intraspecific competition is necessary during predation under both laboratory and field conditions.
Studying the functional response and intraspecific competition will provide insights into the prey-predator and predator-predator interactions between $H$. axyridis and $M$. sacchari, which could result in the development of a better strategy for the biological control of $M$. sacchari using $H$. axyridis. Thus, the objectives of this study were to determine the functional response of $H$. axyridis to $M$. sacchari and intraspecific competition among $H$. axyridis under laboratory conditions.

\section{MATERIALS AND METHODS}

\section{Insect}

Colonies of $H$. axyridis and $M$. sacchari were maintained in the laboratory and a greenhouse at the experimental farm of the Florida Agricultural and Mechanical University, FL, USA. Melanaphis sacchari were reared and reproduced on the leaves of sorghum plants at $16 \mathrm{~L}: 8 \mathrm{D}, 25^{\circ} \mathrm{C}$ and $40-60 \% \mathrm{RH}$. Approximately 20 larvae or adult $H$. axyridis were reared per plastic container (16 $\times 22 \times 8 \mathrm{~cm}$ high) at $16 \mathrm{~L}: 8 \mathrm{D}, 25^{\circ} \mathrm{C}$ and $40-60 \% \mathrm{RH}$. Harmonia axyridis were reared on the sorghum aphid $M$. sacchari from field populations. Prior to the studies, H. axyridis were transferred into Petri dishes ( $9 \mathrm{~cm}$ diameter) containing sorghum leaves infested with $M$. sacchari. Neonates were enclosed soon after hatching to avoid sibling cannibalism; female and male adults were also isolated. Melanaphis sacchari were supplied in $12 \mathrm{~h}$ intervals to guarantee an abundant $H$. axyridis population. For the experiment, individuals of $H$. axyridis were selected for study within $12 \mathrm{~h}$ of molting or eclosing. They were starved for $24 \mathrm{~h}$, and then placed on wet paper discs in Petri dishes including less than 12h-old adults of $M$. sacchari. The dishes were preserved in conditions at $16 \mathrm{~L}: 8 \mathrm{D}, 25^{\circ} \mathrm{C}$ and $40-60 \% \mathrm{RH}$. Adult M. sacchari were not replaced during the tests and nymphs from adult $M$. sacchari were removed every $4 \mathrm{~h}$ by smooth brushes.

\section{Functional response}

To examine the functional response of $H$. axyridis at each developmental stage on $M$. sacchari, prey densities tested were 2, 4, $8,16,32,64,128$ and 256 aphid adults for four instars of larvae (first, second, third, fourth instar) and adults in both sexes (male and female). The number of predation events were examined after $24 \mathrm{~h}$ by recording the number of aphids consumed using binocular microscopes. Each treatment was replicated 10 times simultaneously. Control treatments without predators were performed to take into account the natural mortality of $M$. sacchari adults and the amount of their newborn nymphs in order to correct $M$. sacchari consumption as a function of natural mortality. These treatments were each replicated 10 times.

\section{Intraspecific competition}

To evaluate the effects of intraspecific competition on the foraging behavior of $H$. axyridis, four instars of larvae (first, second, third, fourth instar) and adults in both sexes (male and female) were studied. The prey densities examined were 100, 200, 300, 400 and 500 aphid adults for 1, 2, 3, 4 and 5 predaceous coccinellids at various developmental stages in a Petri dish, respectively. The prey/predator ratio was kept at 100 for each number of coccinellids placed together in a Petri dish, with competition among predators for space increasing with the increasing number of predators placed together. The coefficients of mutual interference were calculated by counting the amount of aphids surviving after $24 \mathrm{~h}$ using binocular microscopes. Each treatment was replicated 5 times simultaneously. 


\section{Statistical analysis}

\section{Functional response}

The functional responses were studied through two-stage analysis (Juliano, 2001). In the first step, cubic logistic regression analysis proportion of prey consumption as a function of initial density was performed to determine the shape (type II or type III) of functional response:

$$
\frac{N_{a}}{N_{0}}=\frac{\exp \left(P_{0}+P_{1} N_{0}+P_{2} N_{0}^{2}+P_{3} N_{0}^{3}\right)}{1+\exp \left(P_{0}+P_{1} N_{0}+P_{2} N_{0}^{2}+P_{3} N_{0}^{3}\right)}
$$

where $N_{\mathrm{a}}$ is the number of prey consumed and $N_{0}$ is the initial prey density. $P_{0}, P_{1}, P_{2}$ and $P_{3}$ are the intercept, linear, quadratic and cubic coefficients, respectively. Negative or positive linear coefficients $\left(P_{1}\right)$ from the regression indicate a type II or type III curve, respectively (Juliano, 2001). If a cubic equation non-significantly yields coefficients, it is desirable to reduce the model by eliminating the quadratic and cubic coefficients from equation 1 and to retest the other parameters (Juliano, 2001). Because the logistic regression analysis indicated that our data fit type II in each case, further analyses were restricted to the type II functional response. The Holling's disc (Eq. 2) (Holling, 1959) was used to model the relationship between the number of prey consumed $\left(N_{\mathrm{a}}\right)$ and initial prey density $\left(N_{0}\right)$ :

$$
N_{a}=\frac{a T N_{0}}{1+a T_{h} N_{0}}
$$

where $N_{\mathrm{a}}$ and $N_{0}$ are described in equation $1, T$ is the total time which in this case is $24 \mathrm{~h}, a$ is the instantaneous searching rate and $T_{\mathrm{h}}$ is the handling time. A nonlinear regression procedure (NLR) based on the Levenberg-Marquardt method was performed to estimate the parameters $a$ and $T_{\mathrm{h}}$. The starting values of $a$ and $T_{\mathrm{h}}$ required by the NLR procedure were found via the linear regression of $1 / N_{\mathrm{a}}$ against $1 / N_{0}$. The resultant y-intercept is the initial estimate of $T_{\mathrm{h}}$ and the reciprocal of the regression coefficient is an estimate of $a$ (Livdahl \& Stiven, 1983; Watson et al., 2000).

\section{Intraspecific competition}

The experiment was performed to calculate the coefficients of mutual interference among predators during predation events. Nonlinear regression analysis was performed to estimate parameters of an intraspecific competition model by fitting equation 3 (Hassell \& Varley, 1969):

$$
E=Q P^{-m}
$$

where $E$ is the mean consumption, $P$ is the predator density, $m$ is the coefficient of mutual interference and $Q$ is the theoretical maximum consumption rate (\%). The values of $Q$ and $m$ were found by power-exponential regressing $E$ and $P$.

Descriptive statistics were given as the mean values and standard errors of the mean. Differences between natural mortality rate and 0 were examined using one sample t-test; $P$ values $<0.05$
Table 1. Maximum likelihood estimates $( \pm S E)$ of the parameters of the logistic model of the proportion of prey consumed versus initial prey density.

\begin{tabular}{lcccc}
\hline Stage & $P_{0}$ & $P_{1}$ & $P_{2}$ & $P_{3}$ \\
\hline First instar & $-2.11638^{* *}$ & $-0.04413^{* *}$ & $0.00025^{*}$ & -4.89855 \\
(SE) & 0.117 & 0.008 & 0.00000049 & 0.26 \\
Second instar & $-1.40043^{* *}$ & $-0.00599^{*}$ & 0.00005 & -0.00000015 \\
(SE) & 0.134 & 0.009 & 0.0000004 & 0.000000043 \\
Third instar & -0.21998 & $-0.00736^{*}$ & 0.00004 & -0.000000063 \\
(SE) & 0.096 & 0.006 & 0.000007 & 0.000000009 \\
Fourth instar & $2.18495^{*}$ & $-0.004014^{*}$ & -0.000036 & 0.000000091 \\
(SE) & 0.549 & 0.037 & 0.000008 & 0.00000002 \\
Adult male & $2.54014^{* *}$ & $-0.053385^{* *}$ & 0.00041 & -0.00000097 \\
(SE) & 0.356 & 0.024 & 0.00007 & 0.00000015 \\
Adult female & $2.25384^{* *}$ & $-0.0136707^{*}$ & 0.000037 & -0.00000004 \\
(SE) & 0.119 & 0.008 & 0.000008 & 0.000000013 \\
\hline
\end{tabular}

* significant at $P<0.05$; ** significant at $P<0.01$.

were considered significant. Statistics were performed with SPSS 20.0 software (IBM, Armonk, NY). Regression analyses were performed using SigmaPlot 12.0 software (Systat Software Inc., San Jose).

\section{RESULTS}

\section{Functional response}

Regardless of prey density, natural mortality rates of $M$. sacchari were not significantly different from 0 (t-test, $P$ $>0.05$ ) as few newborn nymphs were produced during experiments. Thus, the mortality rates of $M$. sacchari and amounts of their newborn nymphs were negligible during tests. Parameter estimates from the logistic model (Eq. 1) of the proportion of $M$. sacchari consumed by $H$. axyridis over a $24 \mathrm{~h}$ period versus prey density are exhibited in Table 1. Estimates of the linear parameter $P_{1}$ were significantly negative for all developmental stages (Table 1). Therefore, the logistic model analysis of all developmental stages performed a type II response to $M$. sacchari.

The functional response data for prey consumption by $H$. axyridis over a $24 \mathrm{~h}$ period fitted the Holling's disc model (Eq. 2) well (Table 2), confirming a type II response for all developmental stages. The amounts of $M$. sacchari consumed increased significantly as their densities increased, and foraging capabilities of $H$. axyridis increased progressively with increasing growth stages (Fig. 1). The coefficients of instantaneous searching rate $(a)$ and handling time $\left(T_{\mathrm{h}}\right)$ indicated numerically this relationship, which had asymptotic $95 \%$ confidence intervals except 0 at vari-

Table 2. Parameter estimates of Holling's disc equation (Eq. 2) for $H$. axyridis attacking $M$. sacchari.

\begin{tabular}{lcccccc}
\hline Stage & $R^{2}$ & $F$ & $P$ & Holling's disc equation & $a$ & $T_{h}(\mathrm{~min})$ \\
\hline First instar & 0.969 & 189.81 & $<0.001$ & $N_{\mathrm{a}}=0.1162 \mathrm{~N} /(1+0.05976 \mathrm{~N})$ & 0.1162 & 740.3 \\
Second instar & 0.964 & 161.297 & $<0.001$ & $N_{\mathrm{a}}=0.2384 N /(1+0.01351 \mathrm{~N})$ & 0.2384 & 81.6 \\
Third instar & 0.999 & 4332.043 & $<0.001$ & $N_{\mathrm{a}}=0.4504 N /(1+0.00460 N)$ & 0.4504 & 14.7 \\
Fourth instar & 0.994 & 917.564 & $<0.001$ & $N_{\mathrm{a}}=0.8818 \mathrm{~N} /(1+0.00240 \mathrm{~N})$ & 0.8818 & 3.9 \\
Adult male & 0.995 & 1230.216 & $<0.001$ & $N_{\mathrm{a}}=0.9607 N /(1+0.00356 N)$ & 0.9607 & 5.3 \\
Adult female & 0.856 & 17.888 & 0.024 & $N_{\mathrm{a}}=0.9881 \mathrm{~N} /(1+0.00207 \mathrm{~N})$ & 0.9881 & 3.0 \\
\hline
\end{tabular}

$R^{2}$ is the coefficient of determination estimated by fitting Holling's disc equation, $P$ is the probability that Holling's disc equation will yield significant parameters, $a$ is the instantaneous searching rate and $T_{\mathrm{h}}$ is the handling time. 

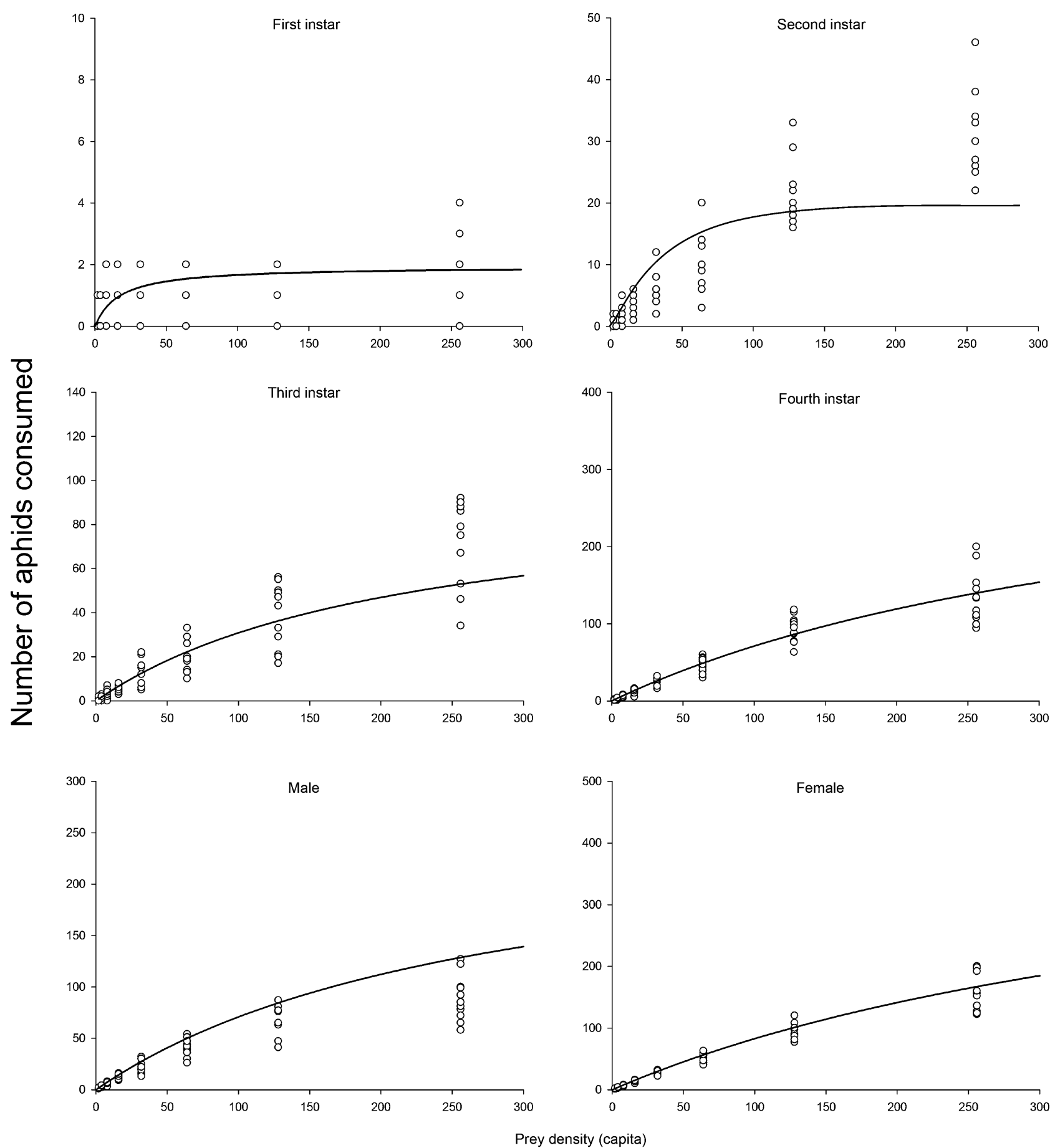

Fig. 1. Functional response of each developmental stage of $H$. axyridis. Solid lines show the functional response curves of $H$. axyridis attacking M. sacchari obtained by fitting Holling's disc equation (Eq. 2). Circles indicate the number of $M$. sacchari consumed at each prey density.

ous developmental stages. The searching rates of female adults $(0.9881)$ were highest among varied developmental stages, followed by those of male adults, fourth, third, second, and first instar larvae. The time of female adults handling a prey $(3.0 \mathrm{~min})$ was shortest, followed by that of fourth instar larva, adult male, third, second and first instar larvae (Table 2).

\section{Intraspecific competition}

When the ratio of prey/predators was kept to 100 , total M. sacchari consumption in a Petri dish gradually in- creased as the introduced numbers of predators and prey increased. However, the mean consumption of ladybugs at various developmental stages decreased with increasing predator and prey density due to intraspecific competition associated with space limitation (Fig. 2). Overall, the mean consumption of ladybugs at five prey-predator densities were $53.4($ prey/predator $=100 / 1), 41.4(200 / 2), 37.5$ (300/3), 33.3 (400/4) and 25.3 (500/5). Intraspecific competition curves fitted the data at all developmental stages of $H$. axyridis with equation 3 . At all developmental stages, the mean consumption at various predator densities fitted 


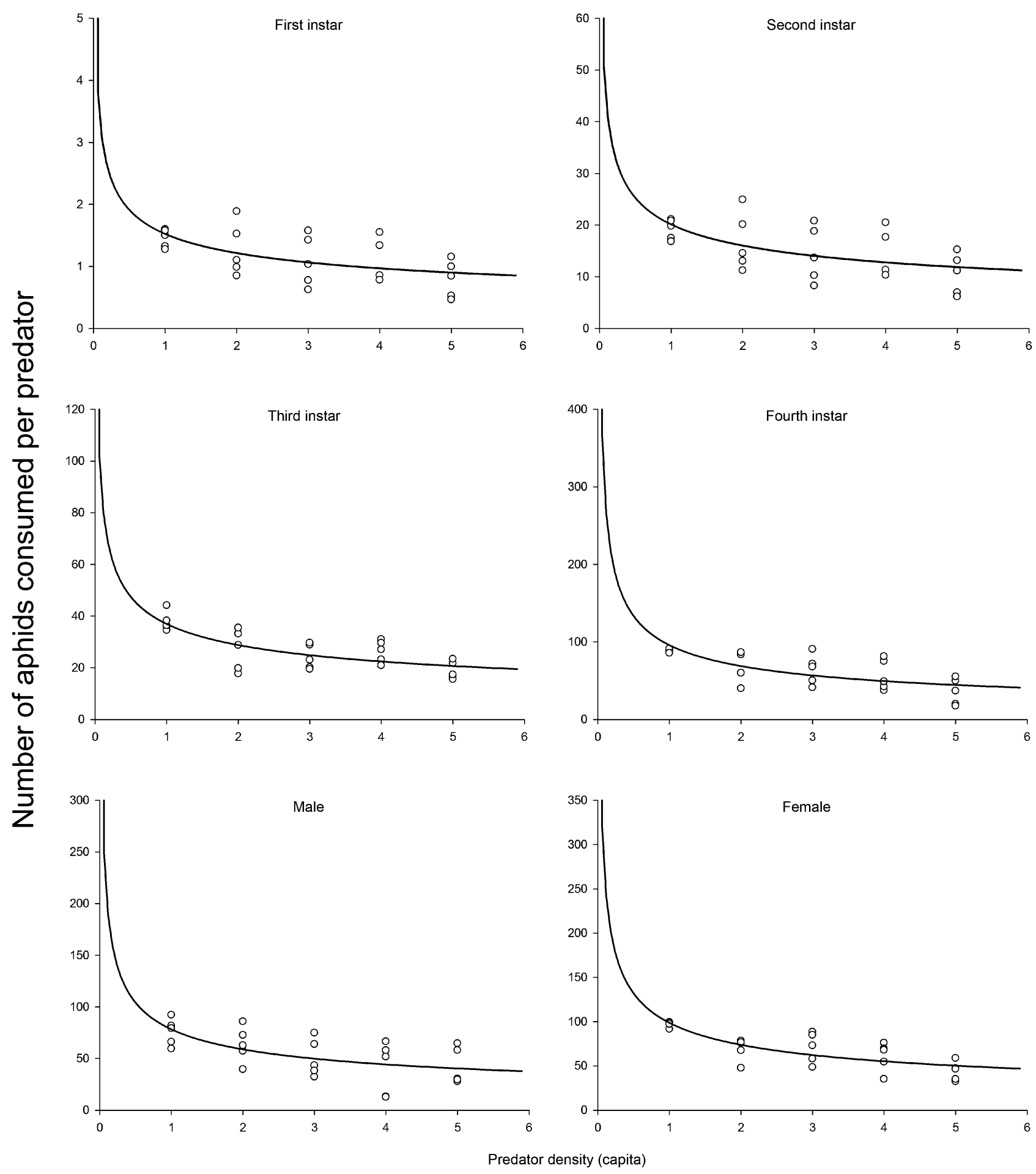

Fig. 2. Intraspecific competition among individuals of $H$. axyridis when attacking $M$. sacchari. Each data point represents the mean number of individuals of $M$. sacchari consumed by an individual predator. The curve was fitted using the intraspecific competition equation (Eq. 3 ).

the intraspecific competition equation well (Table 3). Theoretical maximum consumption rates $(Q)$ and coefficients of mutual interference $(m)$ of all developmental stages had asymptotic $95 \%$ confidence intervals that did not include 0 . The order of theoretical maximum consumption rates $(Q)$ were highest at the adult female stage, followed by fourth instar, adult male, third, second and first instar stages. The order of coefficients of mutual interference $(m)$ were highest at the fourth instar stage, followed by adult female, adult male, and third, second and first instar stages (Table 3).

\section{DISCUSSION}

\section{Functional response}

Our study showed that all developmental stages of $H$. axyridis exhibited a type II functional response against M. sacchari. Type II functional response curves had been reported in previous studies on predation of $H$. axyridis 
Table 3. Parameter estimates of the intraspecific competition equation (Eq. 3) of prey consumption rates of $H$. axyridis at various predator densities.

\begin{tabular}{lcccccc}
\hline Stage & $R^{2}$ & $F$ & $P$ & Intraspecific competition equation & $Q(\%)$ & $m$ \\
\hline First instar & 0.849 & 16.88 & 0.026 & $E=1.5236 P^{-0.3261}$ & 1.5236 & 0.3261 \\
Second instar & 0.848 & 16.752 & 0.026 & $E=20.1223 P^{-0.3275}$ & 20.1223 & 0.3275 \\
Third instar & 0.843 & 16.1 & 0.028 & $E=36.9383 P^{-0.3599}$ & 36.9383 & 0.3599 \\
Fourth instar & 0.805 & 12.377 & 0.039 & $E=95.8276 P^{-0.4764}$ & 95.8276 & 0.4764 \\
Male adult & 0.94 & 47.05 & 0.006 & $E=78.3120 P^{-0.4107}$ & 78.3120 & 0.4107 \\
Female adult & 0.856 & 17.888 & 0.024 & $E=98.6529 P^{-0.4183}$ & 98.6529 & 0.4183 \\
\hline
\end{tabular}

$R^{2}$ is the coefficient of determination estimated by fitting the intraspecific competition equation and $P$ is the probability that the intraspecific competition equation will yield significant parameters.

against different prey species, such as Rhopalosiphum prunifoliae (Lou, 1987), Cinara sp. (Hu et al., 1989), Aphis craccivora Koch (Mogi, 1969), Schizaphis graminum (Hu, 1992), Lipaphis erysimi (He et al., 1994), Myzus persicae (Ma et al., 2000), Myzus nicotianae (Liu et al., 2002), Rhopalosiphum nymphaeae (Ge et al., 2006) and Danaus plexippus (Koch et al., 2003). Holling's disc equation was the most common model to analyze the type II functional response (Fan \& Petitt, 1994, 1997). Our study also showed that the prey consumption increased while the consumption rates diminished with increasing prey densities, which was predicted by Holling's disc model. The result was consistent with past studies that Holling's disc model was suitable to describe the predation of $H$. axyridis on Aphis craccivora Koch (Zhang et al., 2014), Semiaphis heraclei (Zhang et al., 2015), Aphis sophoricola (Liang et al., 2007) and Aphis carvines (Wang et al., 2012).

We found that low foraging success rates were detected in first instars of $H$. axyridis due to their smaller sizes and slower movements (Lee \& Kang, 2004). The larvae in second and third instars had relatively higher M. sacchari consumption compared to the first instar larvae. Fourth instar larvae accounted for $58.2 \%$ of the total prey consumption by larvae, suggesting that fourth instar larvae are the main contributors of aphid consumption by larvae of coccinellids (Hodek \& Honek, 1996). Prey consumption by male and female adults of $H$. axyridis were $74.3 \%$ and $111.3 \%$ of that by the fourth instar larvae over a $24 \mathrm{~h}$ period, respectively, implying the adult and fourth instar stages were equally effective for biological control. Moreover, fourth instars larvae and female adults of $H$. axyridis were more voracious than other developmental stages, likely because of higher nutritional requirements for development or for reproduction (Omkar \& Srivastava, 2003).

\section{Intraspecific competition}

Our study indicated that, although the ratio of prey to predators was kept constant at 100, the foraging efficiency progressively decreased when predator density increased in the Petri dish. Thus, the mean consumption of ladybugs was negatively impacted at a high predator density because of an increased chance of intraspecific competition such as interference or cannibalism (as discussed below). Our findings were consistent with previous studies that intraspecific competition increased with the growing population den- sity of the predatory ladybird Chilocorus spp. (Hattingh \& Samways, 1990).

The intraspecific competition equation for $H$. axyridis yielded the parameters $Q$ (theoretical maximum consumption rate) and $m$ (coefficient of mutual interference), which was consistent with the past studies that the intraspecific competition model (Eq. 3) was performed to estimate the mutual interference of $H$. axyridis during their predation on Aphis citricol (Fang et al., 2013) and Cyamophila willieti (Shen et al., 2009). We found that $H$. axyridis at fourth instar and female stage had higher potential maximum consumption rates and coefficients of mutual interference compared to other developmental stages. Coccinellids are digestive-limited predators, so the limitation of theoretical maximum consumption rate was shown because of predator satiation (Papanikolaou et al., 2014). The coccinellids became inactive after consuming large numbers of aphids at maximum prey consumption, likely minimizing mutual interference, whereas notable time was likely to be spent on mutual interference during their foraging when the ladybugs had high satiation levels (van Gils \& Piersma, 2004; Papanikolaou et al., 2016). Therefore, mature coccinellid individuals had higher coefficients of mutual interference due to higher potential maximum consumption rates.

Cannibalism was occasionally observed when multiple predators shared a Petri dish, as conspecific competitors attacked each other, resulting in injury and sometimes death. Cannibalism contributed to the sharp decline in per capita consumption as predatory density increased, which was another reason why ladybugs at these stages had more severe intraspecific competition. Cannibalism had a negative effect on the overall foraging efficiency, even though it contributed greater resources such as space and food to superior individuals (Block \& Stoks, 2004; Richardson et al., 2010; Bayoumyi \& Michaud, 2015). Another negative effect of cannibalism was increasing disease transmission (Saito \& Bjørnson, 2006) and decreasing inclusive fitness (Hamilton, 1964).

\section{Remaining questions and future perspectives}

Foraging capacities including instantaneous searching rates and handling time are critical for estimating the potential of predators to serve as a biocontrol agent (Lucas et al., 1997). Prey-predator dynamics can be evaluated by a mathematical model (Hassell, 1978). Thus, the dynamics could be established through the functional response curves, and 
the foraging capacity of $H$. axyridis depends on $M$. sacchari density in natural habitats. However, field studies are needed to validate the dynamics, because quantitative models built in laboratory studies appear to have limited value in assessing the foraging abilities under field conditions (Gitonga et al., 2002; Lee \& Kang, 2004). A series of studies on functional responses of Podisus maculiventris verify that there is a distinction between laboratory and field studies (O’Neil, 1988a, b, 1990, 1997; Wiedenmann \& O’Neil, 1991a, b, 1992), likely because of the difference in searching rates of predators between laboratory and field conditions (Murdoch, 1983). Spatial complexity, critical in the natural environment, cannot be recreated under simple laboratory conditions (Kareiva, 1990). Laboratory studies provide parametric analysis of predator-dependent intraspecific competition models, but they are performed only on a non-spatial scale. Thus, intraspecific competition in a spatial sense is critical to future studies as it is closer to natural conditions (Sun et al., 2008, 2014, 2015). Intraspecific competition may disrupt the foraging capacities quantified by functional response. As such, understanding not only prey-predator but also predator-predator interactions is vital for a reliable predator-based control of aphids. Functional response and intraspecific competition models describe the foraging behaviors of predators accurately and also indicate the existence of intraspecific competition impacting their foraging efficiency. Thus, a comprehensive analysis of functional response and intraspecific competition will allow further improvement of our understanding of prey-predator-predator interactions in relation to aphid biological control. Fourth instar larvae and adults of $H$. axyridis can serve as excellent biological control agents of aphids in an integrated pest management programme. Field release of third instar larvae has appeared to be economical as mass rearing to fourth instar and adult stages can be avoided (Seko \& Miura, 2008). Additionally, a suitable predator density should also be considered to decrease intraspecific competition when $H$. axyridis are released in the field, as too few or too many predators released is likely to result in reduced effectiveness of the biological control agent. Moreover, it could be interesting for further studies to regard the intraguild predation in order to obtain more information on the foraging behavior of coccinellids as these interactions have been fitted by several models (de Villemereuil \& López-Sepulcre, 2011; Sentis et al., 2013). Natural stochasticity needs to be considered in future field experiments on intraspecific competition among coccinellids (Papanikolaou et al., 2016). Plant characteristics also need to be considered due to their impacts on the feeding efficiency of predators (Hodek \& Honek, 1996). Future field investigations associated with prey-predator dynamics are critical for effective predator release, which has the potential to reduce pesticide uses and preserve predator populations (Xue et al., 2009).

ACKNOWLEDGMENTS. We thank master student W. Diedrick from Center for Biological Control, Florida Agricultural \& Mechanical University for his assistance with this manuscript. This research was supported by the MOST Program (2015BAD08B03), and Innovative Talents International Cooperation Training Project from China Scholarship Council. References.

\section{REFERENCES}

Akbar W., Showler A.T., Reagan T.E. \& White W.H. 2010: Categorizing sugarcane cultivar resistance to the sugarcane aphid and yellow sugarcane aphid (Hemiptera: Aphididae). J. Econ. Entomol. 103: 1431-1437.

Arimura G., Kost C. \& Boland W. 2005: Herbivore-induced, indirect plant defences. - Biochim. Biophys. Acta 1734: 91-111.

Armstrong J.S., Mbulwe L., Sekulaortiz D., Villanueva R.T. \& Rooney W.L. 2016: Resistance to Melanaphis sacchari (Hemiptera: Aphididae) in forage and grain sorghums. - J. Econ. Entomol. 110: 259-265.

Bayoumy M.H. \& Michaud J.P. 2015: Cannibalism in two subtropical lady beetles (Coleoptera: Coccinellidae) as a function of density, life stage, and food supply. - J. Insect Behav. 28: 387-402.

BEDDINGTON J.R. 1975: Mutual interference between parasites or predators and its effect on search efficiency. - J. Anim. Ecol. 44: 331-340.

Begon M., Harper J.L. \& Townsend C.R. 1996: Ecology: Individuals, Populations and Communities. Blackwell Science, London, $1068 \mathrm{pp}$.

Blackman R.L. \& Eastop V.F. 2006: Aphids on the World's Herbaceous Plants and Shrubs. John Wiley \& Sons, Chichester, $1460 \mathrm{pp}$.

Block M.D. \& StoKs R. 2004: Cannibalism-mediated life history plasticity to combined time and food stress. - Oikos 106: 587-597.

Chang C.P. \& FANG M.N. 1984: Studies on the resistance of sorghum varieties to the sorghum aphid, Melanaphis sacchari (Zehntner). - Chin. J. Entomol. 4: 97-105.

CHOI S.Y. \& KIM G.H. 1985: Aphidvorous activity of a coccinellid beetle, Harmonia axyridis Pallas (Coleoptera: Coccinellidae). - Kor. J. Plant Prot. 24: 11-14.

Colares F., Michaud J.P., Bain C.L. \& Torres J.B. 2015: Recruitment of aphidophagous arthropods to sorghum plants infested with Melanaphis sacchari, and Schizaphis graminum, (Hemiptera: Aphididae). — Biol. Contr. 90: 16-24.

Crowley P.H. \& Martin E.K. 1989: Functional responses and interference within and between year classes of a dragonfly population. - J. North Am. Benthol. Soc. 8: 211-221.

de Villemereuil P.B. \& López-Sepulcre A. 2011: Consumer functional responses under intra- and inter-specific interference competition. - Ecol. Model. 222: 419-426.

DeAngelis D.L., Goldstein R.A. \& O'Neill R.V. 1975: A model for trophic interaction. - Ecology 56: 881-892.

Denmark H.A. 1988: Sugarcane Aphids in Florida. Entomology Circular No. 302. Florida Department of Agriculture \& Consumer Services, Division of Plant Industry, Gainesville, 2 pp.

Dixon A.F.G. 2000: Insect Predator-Prey Dynamics: Ladybird Beetles and Biological Control. Cambridge University Press, New York, $257 \mathrm{pp}$.

FAn Y. \& Petitt F.L. 1994: Parameter estimation of functional response. - Environ. Entomol. 23: 785-794.

Fan Y. \& Petitt F.L. 1997: Functional response, variance, and regression analysis: a reply to Williams and Juliano. - Environ. Entomol. 26: 1-3.

Fang Y.H., Tao M., Ma J., Cao K.Q., Chen G.H. \& Li Q. 2013: Study of the predation functional responses of Leis axyridis Pallas to Aphis citricol Vander Goot. - J. Yunnan Agr. Univ. 28: $306-309$. 
Ferran A., Niknam H., Kabiri F., Picart J.L., Herce C., Brun J., IPERTI G. \& LAPCHIN L. 1996: The use of Harmonia axyridis larvae (Coleoptera: Coccinellidae) against Macrosiphum rosae (Hemiptera: Sternorrhyncha: Aphididae) on rose bushes. Eur. J. Entomol. 93: 59-67.

Ferran A., Giuge L., Tourniaire R., Gambier J. \& Fournier D. 1998: An artificial non-flying mutation to improve the efficiency of the ladybird Harmonia axyridis in biological control of aphids. - Biocontrol 43: 53-64.

Ge Y., Wan L. \& ZhaO S. 2006: Predation of Harmonia axyridis Pallas on Rhopalosiphum nymphaeae Linné (Homoptera: Aphididae). - Acta Agr. Univ. Jiangxiensis (Nat. Sci.) 28: 208-212.

Gitonga L.M., Overholt W.A., Löhr B., Magambo J.K. \& MueKe J.M. 2002: Functional response of Orius albidipennis (Hemiptera: Anthocoridae) to Megalurothrips sjostedti (Thysanoptera: Thripidae). - Biol. Contr. 24: 1-6.

Hall D.G. 1987: The sugarcane aphid, Melanaphis sacchari, in Florida sugarcane. - J. Am. Soc. Sugar Cane Technol. 7: 26-29.

HamiLton W.D. 1964: The genetical evolution of social behaviour. I. - J. Theor. Biol. 7: 1-16.

Hassell M.P. 1978: The Dynamics of Arthropod Predator-Prey Systems. Princeton University Press, Princeton, NJ, 237 pp.

Hassell M.P. \& Varley G.C. 1969: New inductive population model for insect parasites and its bearing on biological control. - Nature 223: 1133-1137.

Hassell M.P., Lawton J.P. \& Beddington J.R. 1976: The components of arthropod predation. I. The prey death rate. - J. Anim. Ecol. 45: 135-164.

Hatano E., Kunert G., Michaud J.P. \& Weisser W.W. 2008: Chemical cues mediating aphid location by natural enemies. - Eur. J. Entomol. 105: 797-806.

Hattingh V. \& Samways M.J. 1990: Absence of intraspecific interference during feeding by the predatory ladybirds Chilocorus spp. (Coleoptera: Coccinellidae). - Ecol. Entomol. 15: $385-390$.

He J.L., Ma E.P., Shen Y.C., Chen W.L. \& Sun X.Q. 1994: Observations of the biological characteristics of Harmonia axyridis (Pallas) (Coleoptera: Coccinellidae). - J. Shanghai Agr. Coll. 12: $119-124$.

Hodek I. \& Honek A. 1996: Ecology of Coccinellidae. Kluwer Academic Publishers, Dordrecht, 464 pp.

Holling C.S. 1959: Some characteristics of simple types of predation and parasitism. - Can. Entomol. 91: 385-398.

Hong O.K. 1996: Studies on the Reproductive Physiology and Laboratory Rearing of the Aphidophagous Ladybeetle Harmonia axyridis Pallas. Ph.D. Thesis, Kangwon National University, $118 \mathrm{pp}$.

Hu G. 1992: Functional responses of larvae of three ladybirds, Adonia variegata, Coccinella septempunctata and C. transversogutata to the aphid Schizaphis graminum (Hom.: Aphididae). - Nat. Enem. Insects 14: 180-185.

Hu Y.S., Wang Z.M., Ning C.L., Pi Z.Q. \& GaO G.Q. 1989: The functional response of Harmonia (Leis) axyridis to their prey of Cinara sp. - Nat. Enem. Insects 11: 164-168.

James D.G., Castle S.C., Grasswitz T. \& Reyna V. 2005: Using synthetic herbivore-induced plant volatiles to enhance conservation biological control: field experiments in hops and grapes. In Hoddle M.S. (ed.): Proceedings of the Second International Symposium on Biological Control of Arthropods, Davos, Switzerland, 12-16 September, 2005. USDA Forest Service, Morgantown, pp. 192-205.

Juliano S.A. 2001: Nonlinear curve-fitting: predation and functional response curves. In Scheiner S.M. \& Gurevitch J. (eds):
Design and Analysis of Ecological Experiments. 2nd ed. Oxford University Press, New York, pp. 178-196.

Kareiva P. 1990: The spatial dimension in pest-enemy interaction. In Mackauer M., Ehler L.E. \& Roland J. (eds): Critical Issues in Biological Control. Intercept, Anover, pp. 213-227.

Kitagami T. \& Ohкubo N. 1998: Release of larvae of Coccinella septempunctata and Harmonia axyridis in greenhouse for controlling Aphis gossypii on strawberry. - Annu. Rep. Kansai Plant Prot. Soc. 40: 151-152.

Kосн R.L. 2003: The multicolored Asian lady beetle, Harmonia axyridis: a review of its biology, uses in biological control, and non-target impacts. - Biol. Contr. 3: 32, 16 pp.

Koch R.L., Hutchison W.D., Venette R.C. \& Heimpel G.E. 2003: Susceptibility of immature monarch butterfly, Danaus plexippus (Lepidoptera: Nymphalidae: Danainae), to predation by Harmonia axyridis (Coleoptera: Coccinellidae). - Biol. Contr. 28: $265-270$.

Kuroda T. \& Miura K. 2003: Comparison of the effectiveness of two methods for releasing Harmonia axyridis (Pallas) (Coleoptera: Coccinellidae) against Aphis gossypii Glover (Homoptera: Aphididae) on cucumbers in a greenhouse. - Appl. Entomol. Zool. 38: 271-274.

LeE J. \& Kang T. 2004: Functional response of Harmonia axyridis (Pallas) (Coleoptera: Coccinellidae) to Aphis gossypii Glover (Homoptera: Aphididae) in the laboratory. - Biol. Contr. 31: 306-310.

Liang H.Z., Hu Y.J., Chen Q., Hou Z.R., Tian H.P. \& Liang X.M. 2007: Functional responses of Harmonias axyridis preying on Aphis sophoricola. - Chin. J. Biol. Contr. 23: 103-106.

Liu J., Wu X., Sha Q., Tan Z. \& Deng J. 2002: Functional responses and density interference effect in Harmonis axyridis Pallas, a predator to Myzus nicotianae (Blackman). - J. Southw. Univ. (Nat. Sci.) 24: 433-435.

LivdAhl T.P. \& Stiven A.E. 1983: Statistical difficulties in the analysis of predator functional response data. - Can. Entomol. 115: 1365-1370.

Lou H.H. 1987: Functional response of Harmonia axyridis to the density of Rhopalosiphum prunifoliae. - Nat. Enem. Insects 9: $84-87$.

Lucas E., Coderre D. \& Vincent C. 1997: Voracity and feeding preferences of two aphidophagous coccinellids on Aphis citricola and Tetranychus urticae. - Entomol. Exp. Appl. 85: 151-159.

Ma F., Lu F., Wei C., Zou Y., Cheng X. \& Wu H. 2000: Predatism of Harmonia axyridis adults on different ranges of starvation to Myzus persicae. - J. Anhui Agric. Univ. 27: 348-351.

McClure M.S. 1987: Potential of the Asian predator, Harmonia axyridis Pallas (Coccinellidae), to control Matsucoccus resinosae Bean and Godwin (Homoptera: Margarodidae) in the United States. — Environ. Entomol. 16: 224-230.

MEAD F.W. 1978: Sugarcane aphid, Melanaphis sacchari (Zehntner) - Florida - new continental United States record. - Cooper. Plant Pest Rep. 3: 475.

Mogi M. 1969: Predation response of the larvae of Harmonia axyridis Pallas (Coccinellidae) to the different prey density. Jap. - J. Appl. Zool. 13: 9-16.

MuRDoch W.W. 1983: The functional response of predators. $-J$. Appl. Ecol. 10: 335-342.

Nibouche S., Fartek B., Mississipi S., Delatte H., Reynaud B. \& Costet L. 2014: Low genetic diversity in Melanaphis sacchari aphid populations at the worldwide scale. - PLOS ONE 9: e106067, $10 \mathrm{pp}$.

OMKAR \& SRIVASTAVA S. 2003: Functional response of the sevenspotted lady beetle, Coccinella septempunctata Linnaeus on 
the mustard aphid, Lipaphis erysimi (Kaltenbach). — Insect Sci. Appl. 23: 149-152.

O’NeIL R.J. 1988a: Predation by Podisus maculiventris on Mexican bean beetle, Epilachna varivestis, in Indiana soybeans. Can. Entomol. 120: 161-166.

O'NeIL R.J. 1988b: A model of predation by Podisus maculiventris on Mexican bean beetle, Epilachna varivestis, in soybeans. - Can. Entomol. 120: 601-608.

O’NeIL R.J. 1990: Functional response of arthropod predators and its role in the biological control of insect pests in agricultural systems. In Baker R.R. \& Dunn P.E. (eds): New Directions in Biological Control: Alternatives for Suppressing Agricultural Pests and Diseases. Alan R. Liss, New York, pp. 83-96.

O’NeIL R.J. 1997: Functional response and search strategy of Podisus maculiventris (Heteroptera: Pentatomidae) attacking Colorado potato beetle (Coleoptera: Chrysomelidae). — Environ. Entomol. 26: 1183-1190.

Papanikolaou N.E., Milonas P.G., Demiris N., Papachristos D.P. \& Matsinos Y.G. 2014: Digestion limits the functional response of an aphidophagous coccinellid. - Ann. Entomol. Soc. Am. 107: 468-474.

Papanikolaou N.E., Nikos D., Milonas P.G., Simon P. \& TheoDORE K. 2016: Does mutual interference affect the feeding rate of aphidophagous coccinellids? A modeling perspective. PLOS ONE 11: e146168, 10 pp.

Pendleton B.B., Copeland A.L. \& Michels Jr. G.J. 2009: Effect of biotype and temperature on fitness of greenbug (Hemiptera: Aphididae) on sorghum. - J. Econ. Entomol. 102: 1624-1627.

Richardson M.L., Mitchell R.F., Reagel P.F. \& Hanks L.M. 2010: Causes and consequences of cannibalism in non-carnivorous insects. - Annu. Rev. Entomol. 55: 39-53.

SAito T. \& BJøRnSON S. 2006: Horizontal transmission of a microsporidium from the convergent lady beetle, Hippodamia convergens Guérin-Méneville (Coleoptera: Coccinellidae), to three coccinellid species of Nova Scotia. - Biol. Contr. 39: $427-433$.

Sasso R., Iodice L., Woodcock C.M., Pickett J.A. \& GuerriERI E. 2009: Electrophysiological and behavioural responses of Aphidius ervi (Hymenoptera: Braconidae) to tomato plant volatiles. - Chemoecology 19: 195-201.

Sero T. \& Miura K. 2008: Functional response of the lady beetle Harmonia axyridis (Pallas) (Coleoptera: Coccinellidae) on the aphid Myzus persicae (Sulzer) (Homoptera: Aphididae). Appl. Entomol. Zool. 43: 341-345.

Sentis A., Hemptinne J.L. \& Brodeur J. 2013: How functional response and productivity modulate intraguild predation. Ecosphere 4: 46, $14 \mathrm{pp}$.

Seo M.J. \& Youn Y.N. 2000: The Asian ladybird, Harmonia axyridis, as biological control agents: I. Predacious behavior and feeding ability. - Kor. J. Appl. Entomol. 39: 59-71.

Shen P., Chang C.X., Zhu H.Y., Wang X.D., Tian W., Zhang Y.Q. \& Han S.Q. 2009: Predation of Cyamophila willieti by the adults of Harmonia axyridis. - Plant Prot. 35: 66-69.

Singh B.U., Padmaja P.G. \& Seetharama N. 2004: Biology and management of the sugarcane aphid, Melanaphis sacchari (Zehntner) (Homoptera: Aphididae), in sorghum: a review. Crop Prot. 23: 739-755.

Sun G.Q., JIN Z., Liu Q.X. \& Li L. 2008: Dynamical complexity of a spatial predator-prey model with migration. - Ecol. Model 219: 248-255.

Sun G.Q., Chakraborty A., Liu Q.X., Lin Z., Anderson K.E. \& Li B.L. 2014: Influence of time delay and nonlinear diffusion on herbivore outbreak. - Commun. Nonlinear Sci. Numer. Simulat. 19: 1507-1518.
Sun G.Q., WANG S.L., REN Q., JIN Z. \& WU Y.P. 2015: Effects of time delay and space on herbivore dynamics: linking inducible defenses of plants to herbivore outbreak. - Sci. Rep. 5: 11246, $9 \mathrm{pp}$.

TAKABAYAshi J. \& Dicke M. 1996: Plant-carnivore mutualism through herbivoreinduced carnivore attractants. - Trends Plant Sci. 1: 109-113.

Tedders W.L. \& Schaefer P.W. 1994: Release and establishment of Harmonia axyridis (Coleoptera, Coccinellidae) in the southeastern United-States. - Entomol. News 105: 228-243.

Trouve C., Ledee S., Ferran A. \& Brun J. 1997: Biological control of the damson-hop aphid, Phorodon humuli (Hom.: Aphididae), using the ladybeetle Harmonia axyridis (Col.: Coccinellidae). - Entomophaga 42: 57-62.

TuRLINGS T.C.J. \& TON J. 2006: Exploiting scents of distress: the prospect of manipulating herbivore-induced plant odours to enhance the control of agricultural pests. - Curr. Opin. Plant Biol. 9: 421-427.

van den Berg J., Pretorius A.J. \& van Loggerenberg M. 2003: Effect of leaf feeding by Melanaphis sacchari (Zehntner) (Homoptera: Aphididae), on sorghum grain quality. - S. Afr. J. Plant Soil 20: 41-43.

VAN GiLS J.A. \& Piersma T. 2004: Digestively constrained predators evade the cost of interference competition. - J. Anim. Ecol. 73: 386-398.

Varley G.C., Gradwell G.R. \& Hassell M.P. 1973: Insect Population Ecology: An Analytical Approach. Blackwell, London. $212 \mathrm{pp}$.

Verheggen F.J., Arnaud L., Bartram S., Gohy M. \& Haubruge E. 2008: Aphid and plant volatiles induce oviposition in an aphidophagous hoverfly. - J. Chem. Ecol. 34: 301-307.

Villanueva R.T., Brewer M., Way M.O., Biles S., Sekula D., Bynum E., Swart J., Crumley C., Knutson A., Porter P., ParkeR R., Odvody G., Allen C. \& Ragsdale D. 2014: Sugarcane Aphid: A New Pest of Sorghum. Texas A\&M Agrilife Extension, Ento-035. URL: http://denton.agrilife.org/files/2013/08/ ENTO-035-The-Sugarcane-Aphid-2014.pdf.

Wang S., Wu D., Zhang F. \& LiU C.Z. 2012: A comparison of predatory function response in different search spaces of a French non-flying form Harmonia axyridis (Coleoptera: Coccinellidae) to Aphis carvines. - J. Environ. Entomol. 34: 80-87.

Watson D.M., Du T.Y., Li M., Xiong J.J., Liu D.G., Huang M.D., RAE D.J. \& BeatTie G.A.C. 2000: Functional responses of, and mutual interference in Aleurodothrips fasciapennis (Franklin) (Thysanoptera: Phlaeothripidae) and implications for its use as a biocontrol agent. — Gen. Appl. Entomol. 29: 31-37.

White W.H., Reagan T.E. \& Hall D.G. 2001: Melanaphis sacchari (Homoptera: Aphididae), a sugarcane pest new to Louisiana. - Fla Entomol. 84: 435-436.

WiedenManN R.N. \& O’Neil R.J. 1991a: Laboratory measurement of the functional response of Podisus maculiventris (Say) (Heteroptera: Pentatomidae). — Environ. Entomol. 20: 610 614.

Wiedenmann R.N. \& O’Neil R.J. 1991b: Searching behavior and time budgets of the predator Podisus maculiventris. - Entomol. Exp. Appl. 60: 83-93.

Wiedenmann R.N. \& O’Neil R.J. 1992: Searching strategy of the predator Podisus maculiventris (Say) (Heteroptera: Pentatomidae). - Environ. Entomol. 21: 1-9.

Xue Y., Bahlai C.A., Frewin A., Sears M.K., Schaafsma A.W. \& Hallett R.H. 2009: Predation by Coccinella septempunctata and Harmonia axyridis (Coleoptera: Coccinellidae) on Aphis glycines (Homoptera: Aphididae). - Environ. Entomol. 38: 708-714. 
Zhang W.Q., Guo X.H., Hou Z.R., WANG L., Yin Z., HaO S.D., Guo Y.Y., Wang J.Z. \& Zhang Z.Y. 2014: The predation functional response of Harmonia axyridis Pallas to Aphis craccivora. - J. Environ. Entomol. 36: 965-970.

Zhang X.M., XI Y.M., Wang S., Luo C. \& Zhang F. 2015: Assessment of potential control of Semiaphis heraclei by Harmonia axyridis. - Chin. J. Biol. Contr. 31: 317-321.
ZeHNTNER L. 1897: Die plantenluizen van het suikenet. - Arch. Suikerind. Ned. Ind. 5: 551.

Received December 27, 2017; revised and accepted April 6, 2018 Published online May 17, 2018 